\title{
THEATRE AS SACRAMENT
}

\section{Paul Woodruff}

All theatre is sacramental. A theatrical event establishes itself as theatre by setting aside a measured space as inviolable for a measured time. This framing effect of theatre is sacramental. Within the frame of theatre, other sacraments can be represented or performed. Part I of this paper develops conceptual distinctions necessary to understanding the sacramental in theatre, using an ethicsbased theory of sacrament. Part Il sets out to use the theory, applying it to open up new questions for the interpretation of ancient Greek tragedy, and using the theory to explain certain plot elements in Sophocles' Philoctetes and other plays.

\section{Theatre as Sacrament}

Any act of theatre has a sacramental effect. ${ }^{1}$ The art of theatre makes ceremonies possible, and by ceremonies we are able to make things sacred. In saying that theatre is sacramental, I am not saying that it is religious. Religious ceremonies employ the art of theatre and depend on that art, but theatre does not depend on religion. I understand sacrament as an ethical concept. A sacrament sets up an ethical hedge around something-makes it wrong to touch, to tread on, or to alter the thing in question.

By 'theatre' I mean the art that makes action worth watching for a measured time in a measured space. This art must of necessity draw a line between watching and being watched. Drawing that line is a minor, though fundamental, sacrament. Other sacraments may take place within the frame of theatre. My theory of the sacramental in theatre stands on its usefulness for understanding and interpreting the elements of theatre-the experiences of both the watchers and the watched in actual productions, on the one hand, and, on the other, the texts that survive to represent productions of the past. If the theory is coherent and useful, then we should use it. Otherwise, not.

As to the origins of theatre in the ancient Greek culture or any other, I make no claims. To understand theatre and the sacred anthropologically would require a detailed study of human cultures, but that is beyond my range as a philosopher. My part in this is limited to identifying the main questions and laying a few blocks of the foundation for what needs to be done. As a classical scholar, I observe a sacramental element in the earliest European theatre, an element that survives as a legacy in theatre of our own time. As a philosopher, I make distinctions and draw connections among ideas. My work is at best a prologue to research by scholars of the human landscape. A prologue of this kind is necessary, however, in order to clear up the conceptual landscape, which has been scarred by debates over religion. At the same time, this is a prologue to asking new questions in the interpretation of the texts of ancient plays. 


\section{PAUL WOODRUFF}

\subsection{Sacraments and the Sacred}

Under 'sacrament' I include any action that makes (or helps to make) something sacred-an action that consecrates. I also include actions that deconsecrate anything previously made sacred.

By 'action' I mean an event caused, in some degree, by human choice.

By 'sacred' I mean anything that has been given, by human action, any of a set of ethical properties that I will call hedging properties.

By 'hedging properties' I mean such properties as being untouchable. The ethics of a sacramental culture forbid us from interfering with the sacred-we should not tread on sacred ground, get in the way of a sacred person, violate a sacred friendship, or abuse a sacred object. To interfere with what is sacred is a failure of respect-the ethical virtue that calls us to treat other people, and therefore the things that other people care about, with respect. Hedging properties are expressed by any of a set of strong protective rules, such as 'don't touch', 'do not injure', 'do not enter', and 'do not interrupt'; these rules are further qualified by clauses with 'unless', such as 'unless you wash your hands', or 'unless you undergo a certain ritual afterwards', or 'unless you take off your shoes', or 'unless you have been consecrated', or 'unless you are dressed in a certain way'.

The sacred thing could be a place, a time, a person, a friendship, an oath, a physical object, a ceremony, or anything else with the relevant ethical properties. Prior to sacrament, a candidate for sacredness need have no special properties. It need not be beautiful or awe-inspiring. A shack can be set aside for praying, a scruffy plot of ground can be a marked off for performance or play, the ugliest and most disreputable of men or women may be given a sacred role in ritual. There need be nothing about these that makes them untouchable, prior to their being made so by human action.

Furthermore, making something sacred is not in itself an act of approbation. A curse on something that is dreadful may make that thing sacred in my sense. ${ }^{2}$ This is the dark side of the sacred and is closely related to pollution, a subject that I shall not take up in these pages.

Everything sacred is untouchable either literally or figuratively. Breaking an oath that has been consecrated is touching (figuratively) the untouchable, as is violating a consecrated marriage. But not everything that is untouchable is sacred. Human excrement is untouchable in most cultures, but not because it is held to be sacred; the same goes for a poisonous viper. The danger of its poison makes it untouchable; the viper may also be sacred in some cultures, but its poison alone is not what makes it so.

Generally, cultures have allowed the untouchable to be touched under certain circumstances. Some sacred places or objects should not be touched at all; some should be touched only by people who have been consecrated to do sopeople who are then, in a sense, sacred. There is a class of sacraments that mark off the people who are permitted to enter sacred space or handle sacred objects. An action that exempts a person from the hedging properties is thus a sacra- 
ment. Consecrating priests, for example, gives them the status to enter places others may not. An action that removes hedging properties from an object altogether-that returns the object to ordinary status -is also a sacrament. A curse may be lifted, a church may be made a shopping mall, a priest may be defrocked, and a marriage may be undone.

The boundaries that define the sacred are not bright; we can identify central examples of the sacred, such as the aduton of a temple in ancient Greece, the Sabbath day for Jews and some Christians, or the Koran for adherents to Islam. And then there are cases of the sacred that are further from the centre, such as a football field during play, or the stage of the Metropolitan Opera during a performance.

You need not belong to a given culture to recognise and abide by its sacraments. The hedging rules apply across cultures. Visitors should respect whatever the culture they visit takes to be sacred. And what they should do, they can. Respect involves feelings. A Christian can feel that it is right to remove shoes before entering a mosque; an atheist can feel that it is right to maintain silence during a mass. One need not believe in anything divine or transcendent in order to recognise the importance of the sacred, or even to take part in performing a sacrament that makes something sacred. Anyone with an adequate allotment of human virtue should be capable of respecting what a culture marks off as sacred.

The sacred is essentially related to the ethics of respect, but it is only contingently related to religion. True, sacraments and the sacred are often embedded in religious practice and belief, and some traditional cultures do not distinguish religious practice from other social practices, such as in politics or the arts. Modern secular cultures isolate religion in order to allow for diversity and choice, but traditional cultures, including that of ancient Greece, consider most social activities to be permeated with religion. For such a culture we cannot ask a well-defined question as to whether a given practice is religious.

The philosopher Nietzsche, who was hardly a believer, nevertheless had enormous respect for the sacred, and faulted scholars for not appreciating the subject:

The way in which respect ${ }^{3}$ for the Bible has, on the whole, been maintained in Europe might be the best piece of discipline and refinement in manners that Europe owes to Christianity. Books with this sort of profundity and ultimate meaning need the protection of an externally imposed tyranny of authority; this way, they can last through the millennia that are needed to use them up and figure them out. It is a great achievement when the masses (people of all kinds who lack depth or have speedy bowels) have finally had the feeling bred into them that they cannot touch everything, that there are holy experiences which require them to take off their shoes and keep their dirty hands away, - and this is pretty much as high a level of humanity as they will ever reach. 


\section{PAUL WOODRUFF}

Conversely, what is perhaps the most disgusting thing about so-called scholars, the devout believers in 'modern ideas', is their lack of shame [Scham], the careless impudence of their eyes and hands that touch, taste and feel everything. ${ }^{4}$

As an unbeliever, Nietzsche is making an ethical point about refinement. Clearly the point is not restricted to the Bible; he would like to see such refinement extended to other areas, evidently not restricted to objects related to the Christian God. He is concerned for the survival of the ability to recognise and treat the sacred, wherever it is found, with respect.

Secular examples abound, that is, examples outside what we usually consider the boundaries of religion. Walking on to the stage during a theatrical performance, when you are not a member of the cast, is touching the untouchable. So is interfering with the players in a game-for example, throwing a stone from the stands at a player on the team you oppose.

By placing the concept of the sacred firmly within human cultures, I mean to draw a line between the sacred and the transcendent. I have argued elsewhere that what we recognise as transcendent is worthy of awe and reverence-God for example, or Platonic Justice. ${ }^{5}$ God is not thought to be sacred. It is not in our power as human beings to trample on or pollute the transcendent. The point is nicely made by Euripides, when he has Theseus confront Heracles over the pollution he carries as the killer of his family: Heracles could pollute a city if he went there to live, but he cannot pollute heaven itself:

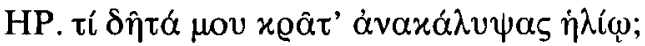

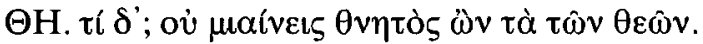

(Eur. Her. 1231f.)

Her.: Then why not let me hide from the sun?

Thes.: So what? You're human. You can't pollute what belongs to gods.

The sacred is different from the transcendent in that human culture creates the sacred through sacrament, but does not create the transcendent. By 'sacred' I do not mean 'holy' as it is used as an epithet of the divine. The sacred is made so by human action, not by divine presence. If we believed otherwise, our theory could not cover the secular examples of sacrament that are essential to the art of theatre. There is, however, a connection between sacrament and divine presence: a sacrament may prepare the ground for divine presence.

Human cultures create representations of the transcendent, but a representation is not the same as the thing represented. ${ }^{6}$ An image of the Virgin Mary housed in a church is sacred, and therefore we owe it a certain kind of respect, even veneration, while if we owe reverence, we owe it to Mary herself. A graven image is at best a reminder of the transcendent. Reverence is due to 


\section{THEATRE AS SACRAMENT}

things that are beyond human ability to make or mar; respect is due to human beings and their creations. The distinction is an ethical one?

\subsection{Frames: Making Space or Time Sacred}

Many different sacraments may be achieved in theatre, but all successful theatre achieves the sacrament of making a space untouchable for a time. The art of theatre (as I define it) makes human action worth watching in a measured space and for a measured time. ${ }^{8}$ Time in theatre is measured by the plot, the arrangement of the actions to be watched. Space in theatre is often measured formally, as by the circle that marks the orchestra of an ancient theatre, by the white lines that indicate the boundaries of a playing field, by the proscenium of an old-fashioned stage, or by the iconostasis of an orthodox church. In the absence of formal boundaries, space in theatre is simply the space used by the actions that are being watched.

Where the action is, the audience does not go, except under special circumstances, which I will discuss below (the 'altar call'). For the audience to enter a playing field while the action takes place is a major transgression. Before or after the game, it is often permitted, although other rules may apply (such as to protect the grass). Transgressions are very interesting, of course; they are interesting because the audience is aware of the boundaries and feels that something significant has happened when they are crossed. ${ }^{9}$ Transgressions by children and foreigners show the importance of cultural convention to sacrament; very young children or visitors from distant cultures may stray into sacred space, although they may instead pick up cues from those around them and respect the sacred without knowing why. Convention is only part of the story, however: the sacred is found in all cultures. So it is not surprising that a spellbinding storyteller, or a captivating drama, should awaken respect for the sacred in a child too young to have yet learned the customs.

Once a theatrical ceremony begins, a kind of sacredness falls over the space where it takes place, and that sacredness lasts until the ceremony ends. Then, if a space remains sacred it does so for reasons unrelated to theatre: a ritual of consecration can make a church sacred until it is deconsecrated. But the art of theatre in and of itself consecrates and deconsecrates space whenever and wherever it is practised. That is why I can say that all theatre is to some extent sacramental: it makes its space untouchable-except for those whom it consecrates to enter it.

A framing sacrament does not take place without notice: at the start the curtain rises, an anthem is played, a ball is thrown, or an opening prayer is given; the ending too is marked, in theatre with applause or a curtain, in a service with prayer. But although we recognise that the designated space is untouchable for the time that is marked in this way, we rarely recognise the framing as sacramental. For all that, it is a sacrament because it makes something untouchable.

Not all framing sacraments are theatrical. Ancient Greeks held both sporting events and theatrical events inside precincts that were sacred at all times $;{ }^{10}$ dur- 


\section{PAUL WOODRUFF}

ing the actual events they are even more sacred, but only for the time measured by the event.

Within the frame of theatre, further sacraments may be represented or actually performed, or represented and performed at the same time. Representation belongs to mimesis, which, as I have argued elsewhere, may cross reality in at least two ways."

First, mimesis may occur simultaneously with action. An actor plays the part of a man who takes a seat on stage; the actor truly is, at the same time, taking a seat on stage. A hunter may imitate the call of a moose summoning another moose; in doing so, the hunter is actually summoning a moose. In the same way, an actor may play the part of a woman who invokes a god; this actor may actually be, at the same time, invoking the god. Whether this is so or not is hard to determine for ancient plays; the performer would have known, and so probably would the audience.

Second, mimesis can bring about an actual change. A child emulates his mother by copying her actions; he does this so he may become like her, and in due course he is truly doing what she does, without mimesis. In a religious ritual, a dancer may wear the mask of a god, and, as the dance progresses, become the god for a time (or so the dancer and the people believe). An actor playing the part of a suppliant may thereby become a suppliant. These possibilities emerge from a clear understanding of the relation between mimesis and reality.

\subsection{Sacrament and Epiphany}

Some sacraments aim to bring the divine into presence, or epiphany. Some sacramental rituals are thought to bring the transcendent to earth and implant it, at least for a time, in an ordinary person or object, and these rituals are sacraments of a special sort. Such sacraments generally occur within a theatrical frame. The traditional Christian mass takes place in consecrated space during a time that is marked at beginning and end; it is supposed to bring God's blood and body into wine and bread blessed by the consecrated priest. This is believed to be transubstantiation, a change in reality. In some traditional religions, ecstatic dance theatre begins through mimesis of a god by means of mask and motions, but ends when the god descends into the dancer, for the remaining sacred time of the dance. During that time the dancer is sacred and must not be interfered with, while the god in him may be believed to be transcendent and treated with reverence. If we are in awe, we are in awe of the god, not the dancer. Kletic hymns in classical Greek religious practice, which I will discuss below, were calls to a god to come into the presence of the people. Some ancient Greek tragedies represent epiphanies, by introducing a god from a machine above the acting space.

An ethics-based theory of the sacred is neutral on questions of whether transubstantiation actually occurs and whether rituals can bring gods into presence. The ethical point is that the ritual creates a sacred occasion, which calls for 


\section{THEATRE AS SACRAMENT}

respect. For the time, in the place, one should keep holy silence, and one should particularly not mess with whatever object or person is supposed to be the receptacle for the divine.

The epiphany is not a sacrament, since it is not accomplished by human action. Whether the god makes herself present in the dancer is up to the god; it is up to us to respect the dancer and the occasion of the dance. The preceding sacrament consecrates an occasion for epiphany and its elements. Summoning the god is sacramental; the god's appearing is not.

\subsection{Consecrating performers}

Priests may enter the inner sanctum. Actors may enter the stage. Players and referees may enter a playing field. But not any actor or any stage. Flashing a card proving my membership in Actors' Equity will not allow me to stroll on to the stage while a group of students is performing Hamlet. NFL credentials will not permit me to run on to a field where one university team battles another. This rule relaxes when theatre is not taking place, during a practice session or rehearsal. Then the space is not sacred; coaches and directors and costumers and set dressers are free to roam, subject to the needs of the process.

Theatre, the art that presents the action to be watched by an audience, makes space sacred in the relevant way; the art of theatre is intrinsic to any ritual that sets up a frame for watching. Theatre does so not only by consecrating the space, but also by consecrating those who may enter it. They too become untouchable while they are in the sacred space-except by each other.

They prepare. Referees wear neutral uniforms. Players wear uniforms indicating their team membership. Actors may wear makeup or masks or costumes. Priests wear vestments. But these are only outward signs, and may be dispensed with if the art of theatre is powerfully enough employed. A naked priest is still a priest, after a shipwreck; she may still function as a priest if she knows her job and her audience knows how to be her audience.

Costumes and uniforms and vestments are outward signs of something: we may reasonably ask what they are signs of. Part of the real preparation is mental: you must know what you are about to do, and you must know that it is not your everyday self that is about to do it. This morning you were a boy who could throw a ball; now, you are the team's pitcher and you know it. This sacrament requires your willing participation as a necessary condition. Willing is not enough, however; all the will in the world will not consecrate you by itself to run on to the playing field.

We have two more necessary conditions for consecrating people to enter the sacred space of theatre: the audience must be prepared to accept you, under the conventions of their theatre, as entitled to enter the space. And all those who are consecrated to enter the space must also accept you in this role. The art of theatre operates under local conventions, clear to those who take part on both sides of the line that marks the sacred space. 
One is not simply consecrated to enter a space; one is consecrated for a particular role. Priest and altar boy are marked alike to go where others do not, but they are marked for different roles. Some roles are intermediary, like the role of a referee, who is a watcher on the field and makes judgments on behalf of, or in place of, all the watchers. Similarly, the chorus in an ancient Greek play has an intermediary role between audience and represented action; at the same time, the chorus has a role inherited from other rituals, as intermediary between the community and the gods.

\subsection{Crossing the line: self-consecration}

Purely mimetic theatre does not invite its audience on to the stage or into its sacred space. Such an invitation would give the audience an opportunity to make something real happen to them. Foreclosing on that opportunity is a high cost for purely mimetic theatre to pay. In a religious ceremony (which is not mimetic), an altar call is an invitation to members of the audience to consecrate themselves. They cannot come to the altar unless they know where the altar is and are nearby - just across the line. Coming to the altar is not significant for them unless it entails crossing into space that is, at the time, sacred. Since you make the decision to accept the altar call, when you do so you consecrate yourself for the purpose. In a religious context, the altar call transforms lives. In an academic context, inviting students to cross the line between them and the professor, to do research and present it as the professor does, is also a kind of altar call that transforms lives.

At the end of a theatre piece, those on stage may break into a dance and invite the audience to join them. That is an altar call, albeit not a transformative one, unless the theatre piece has established significance for the ritual performed in its sacred space, so that joining the ritual means more than joining a party or celebration. Mourning Matthew Shepherd at the end of the Laramie Project, with tears and candles, was a reverse altar call: instead of inviting the audience to come on stage, the performers enlarged the stage so that, suddenly, we were all part of it. In other ways too, performers may enlarge the sacred space, casting it wider and wider so there is no longer an audience, so that all are together..$^{12}$

\subsection{Framing a safe place}

The dead in a veteran's mind ask him why he did not save them (if they were his friends) or why he participated in their deaths (if they were his enemies). Medics, I believe, carry the heaviest burden of people on their own side whom they could not save. But even veterans of the so-called good war, World War II, have told me that they agonise over memories of German boys they have killed.

Perhaps the truth will help-not merely telling it or writing it or acknowledging it, but giving it a temporary life through performance of war or its af- 
termath. Performance leads to a kind of human wisdom: living a role as villain or victim or something in between gives one an understanding of the sources of human action. Allowing oneself to play a role very like one's own gives one an opportunity to express things one would not dare to say among the people with whom one now tries to live in peace-expressions of extreme violence, fear and shame. So veterans have found the Theatre of War healing. ${ }^{13}$ Performing, as well as watching, the theatre of war may have healing effects for two reasons, both based on framing.

Framing in space helps, because the action in theatre occupies a sanctified space that is insulated from our own, and therefore safer. What happens in that isolated world, we feel, does not have to cross the line into our own lives. Framing in time helps as well, because it reassures us that what goes on in that space will not go on forever. Veterans involved in a performance that releases memories of warknow that they will be safe in the long run. They can go back, after the curtain, to being who they are in peacetime. The final applause will release them from memory into life-at least for now.

\section{Questioning Greek Tragedy}

What is the relation between ancient Greek tragedy and religion? Scholars disagree as to how closely Athenian theatre of the classical period was linked to religious ritual, both in its archaic origins and in its classical practice. The deflationary view is that the performance of ancient tragic plays at a theatre of Dionysus was a contingent matter; the plays performed there have little more to do with Dionysus than concerts in Heinz Hall in Pittsburgh have to do with ketchup. ${ }^{14}$ Other scholars see tragic performances more in the light of religious rituals. ${ }^{15}$ The truth may lie between the extremes, and cannot in any event be ascertained. The attitudes of the ancients are not fully evident to us. I will take no position on the issue in this essay; sacrament entails ritual, but not necessarily religious ritual.

I shall not ask here how tragedy in general relates to Athenian religion, but 1 will ask about rituals represented on the tragic stage, what significance they have for performers or audience, whether, for example, prayers delivered by the chorus leap out of the frame and become Athenian prayers to the god. These rituals must be treated on a case-by-case basis; there can be no general rule. In any event, we should not try to draw a bright line between what is religious and what is not-certainly not in classical Greece, and probably not anywhere. Religion and its rituals are too deeply ingrained in human cultures to be set clearly apart.

First I will take up a safer topic-sacraments of framing. For sacraments of framing, religious ritual is relevant only as a paradigm example, and probably also as a distant ancestor. 


\section{PAUL WOODRUFF}

\subsection{Framing and safety}

The great age of tragic theatre in Athens was also an age of exceptionally intense, almost unbroken warfare, which affected everyone in Athens, both those who fought and those who stayed at home, fearing for the soldiers and for themselves. The experience of war was therefore central to the experience of life for both performers and audience. Even the stay-at-home wife is represented, her plight here expressed by a chorus of unmarried women:

Her mind is sick with longing - that is what I have heard-

And Deianeira, the battle trophy, is always

Like a bird in misery of longing.

She cannot even sleep without tears:

Her mind is full of her man,

She is nursing fear

For his travels...

(Soph. Trach. 103-09)

Theatrical framing puts violence, fear and anger into a safe place - an untouchable place if my general theory is right-and by doing so offers opportunities for reflection, understanding and, perhaps, healing.

Peter Meineck has designed productions with this thought in mind. His current production of Euripides' Herakles is a representation of post war madness and suicide-prevention, designed for today's veterans to appreciate. The production is not designed to explore the original meaning of the play, and a critic might reasonably say that Meineck has used an ancient play for a modern purpose. $^{16}$

Nevertheless, Meineck's proposal that we take Athenian theatre as a theatre of and for veterans deserves serious coisideration. Veterans' themes abound in ancient Greek literature, from the earliest tales of nostoi to the tragic poems of the classical period. The plot of the Oresteia begins with a return from war. Of Sophocles' surviving plays, five deal directly with the after-effects of war on soldiers and their families-Electra, Antigone, Women of Trachis, Philoctetes, and Ajax. The popularity of such stories indicates that they were powerful emotionally for their audiences. Audiences of modern veterans also find them powerful and sometimes therapeutic: watching, we veterans feel we are not alone, we see that others have suffered the effects of war, we hear their passions bursting out in performance, and so we are spared the danger of expressing such passions on our own part. As readers or performers, we give voice to these passions within the frame of theatre, safely, and with the sense that theatre makes our wounds untouchable. Exposing them inside the frame does not open them to being rubbed raw by outsiders. ${ }^{17}$ Ancient Greek theatre provides us with the safety of an additional frame: myth itself is framed as safely removed from human life. 
What works for us probably worked for the original audience. We have no reason to believe that it did not. We are, however, so far divided by cultural distance from the ancient Greeks that we should be cautious in drawing general conclusions from our own experience of their plays. Still, experimenting through performance yields empirical evidence of what a performance of a given text can achieve.

Further research in this area could proceed experimentally through original production techniques, or through close study of the reception of tragic performances in antiquity. However illuminating for us the results may be, they must be regarded as highly speculative. But they may be illuminating, as we ask what therapeutic or emotional effects may be due to theatrical framing.

\subsection{The Chorus and Dionysus}

The chorus in ancient Greek tragedy are consecrated to enter the performance space, and they are consecrated for more than one role. First, they are masked and costumed to represent people of a far-off time and place, often of another gender. Second, during the episodes, they (or their leader) often take a direct part in the action of the play. In the Antigone, for example, the chorus of elders acts as the ruler's council, ratifying Creon's ruling against the burial of Polynices (Ant. 211-14); later, they will twice intervene to affect Creon's judgment (Ant. 770, 1091-1107). Third, they can provide stage directions, telling the audience who it is that is entering, and what expression should be seen on a mask (e.g. Ant. 526-29). Fourth, during episodes, and sometimes during odes, ${ }^{18}$ the chorus reacts to the action in much the same way as the audience will react; like cheerleaders at a modern game, they sometimes lead the audience in horror and grief. 'Grief-leaders', we might call them. In this role, as leaders of audience response, they represent the audience, as fellow Athenians. Fifth, they often step out of the roles for which they are costumed and express moral or political views that Athenians generally held. ${ }^{19}$ Their role as Athenians would be no surprise to the audience; the very masks they wear imply that they are in fact Athenians ${ }^{20}$ who have trained long and hard for this role, and are eager to win a prize for their sponsor.

The chorus, then, often works astride the frame, and not strictly within it, as an intermediary between the audience and the action. Therefore we should not be surprised if we find that the chorus also acts as an intermediary between the audience and the gods. Indeed, that is what Athenians generally expected a chorus to do-to call upon the gods and honour them with song and dance on behalf of all Athenians. ${ }^{21}$

As trained dancers in a ritual performance, the chorus probably felt they had a special association with Dionysus, who, after all, was the god of dance. They invoke Dionysus in the Antigone, when they propose to dance in celebration of victory (154) and address him as Chorus-Master later in the same play: i⿳亠 Jû $\varrho$

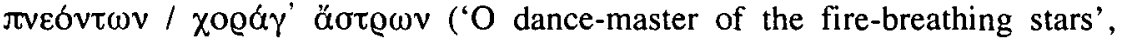
1146f.). 


\section{PAUL WOODRUFF}

The chorus has a connection with Dionysus beyond their role as dancers. They recognise the characters as the characters they are, and, as representatives of the audience, they confirm that the actors are, for the time, the people they are costumed and masked to be. In this way they put the final seal on the sacrament that invites these actors to enter the theatre space, as if to say 'This is Creon, we recognise him, he belongs here with us in this space'.

In effect, the chorus is acknowledging a kind of shape-shifting that is the province of the gods, and especially of Dionysus. Of course all the gods were believed to be shape-shifters. Often engaged in mimesis, sometimes genuinely inhabiting the bodies of animals or men, the gods were models for performers in theatre. Dionysus, the god of many appearances, is an especially appropriate patron for theatre:

Be seen as a bull, be seen many-headed, Be seen as a serpent, or lion blazing fire. Bacchus, come with laughing face...

(Eur. Bacch. 1018-21) 22

Earlier, Dionysus has said that when Pentheus sees Dionysus as a bull, he is seeing things at last as he ought to see them (vv̂v $\delta$ ' ọâ̧ $\grave{\alpha} \chi \varrho \eta^{\prime} \sigma^{\prime}$ ógâv, Bacch. 924). The chorus leads the audience in the Dionysian program of seeing things as they are within the frame of the play. ${ }^{23}$

\subsection{Epiphany}

Euripides' Bacchae records the idea that ritual, especially dance, brings the god among the dancers. Ancient Greek tragedies often contain a choral hymn that summons a god to the action represented in the play; audiences may well have felt that the summons was answered, literally, and that the god came to the theatre. After all, theatre for the ancient Greeks was performed at a religious festival in honour of Dionysus.

No character in Antigone appeals to Dionysus during an episode, but the play's chorus declares a Dionyisan celebration as they enter (lines 153-54), and they later formally summon him in the brilliant fifth stasimon. This is one of our finest examples of what is known as a kletic ode, familiar in ancient tragedy, invoking the presence of the god:

You hold Thebes in honour

Above all cities;

Your mother too,

Thunderstruck woman.

And now we pray: Watch over us:

The violence of plague

Strikes all our people.

Come, your presence is healing. ${ }^{24}$ 
Soar above Parnassus,

Or cross the howling straits of the sea.

$O$ Leader in the dance of stars,

That circle across the night,

Breathing fire,

O shepherd of dark voices,

Child of Zeus, let us see you now.

1150

Come, O Lord, with your throng of Maenads

Iacchus, steward of joy,

Grant them ecstasy

To dance all night for you.

(Soph. Ant. 1134-54) ${ }^{25}$

In Athens' precinct that is sacred to Dionysus, this chorus of Athenian youths, playing the part of Theban elders, sings 'Let us see you now'. Is their prayer real or mimetic or both? These young men believe in the power of Dionysus; most of them have been, or will be, initiated into the mysteries at Eleusis where Athenians are born again into a special relationship with Demeter and Dionysus, mentioned in the first strophe..$^{26}$ Now they are singing and dancing in his honour in his sacred place: could they be merely playing at prayer? Scholarly opinion is divided, and so is mine. ${ }^{27}$

We have two kinds of reasons for taking it as a real prayer: First, it does not spring by probability or necessity from the plot of this ancient tale of Thebes; the best remaining explanation is that it comes from the fervour of contemporary Athenians. Second, the ode is thrilling in its imagery and expression; $I$ find it hard to read without a shiver. Simply, the ode feels like a genuine prayer. If it is a genuine prayer, it leaps out of the frame to make the occasion more sacred than the frame alone could have done. It prepares the audience to feel the unseen presence of the god.

On the other side, we have reasons for taking the prayer to be mimetic. First is its place within a mimetic frame; but, as we have seen, mimesis does not exclude actually doing things. An actor playing the part of a dancer is actually dancing. So the argument from mimesis fails. Second, the Chorus members are playing a part when they summon Dionysus to protect the city of Thebes, for they have no interest, as Athenians, in protecting the rival city. This is the strongest reason for taking the ode to be mimetic.

Even if summoning the god here is mimetic, it is nevertheless a represented sacrament: it ratchets up the sacredness of the occasion within the frame by setting up a frame within the frame-a frame for the epiphany of Dionysus within the general frame of theatre. Although the plot does not require the presence of Dionysus, or even make it probable, invoking it at just this point is effective theatre. The audience knows that Creon is about to discover something dreadful, for which the heightened atmosphere created by the ode is appropriate. Besides, theatrical magic has been at work on the actors and on the imagin- 


\section{PAUL WOODRUFF}

ations of the audience from the opening lines, and we have seen that this is $\mathrm{Di}$ onysian. And now, although the plot does not need Dionysus, and although no one will see him arrive on a machine, this brilliant ode has made palpable the role of Dionysus in the action that is to follow, as if to say, "Show more respect than before; pay closer attention; and don't be surprised by what is coming: the god might be an unseen presence among us'.

\subsection{Making the Hero Sacred}

Oedipus does this to himself. Not knowing whom he is cursing, he calls down a curse on the killer of Laius, and this curse will make him untouchable. The audience witnesses this sacrament, early in Oedipus Tyrannus:

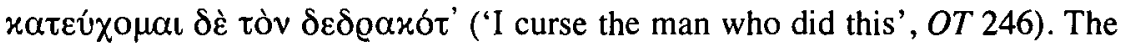
curse, added to the pollution that a parricide carries, will put Oedipus beyond the pale.

Not only do we see the sacrament; we see it take effect: After the truth is known, the chorus members shrink from Oedipus (implication of 1413-15), his children are torn out of his arms (1521f.), and he is to be taken indoors where the sun will not be defiled by shining upon him (1424-31). He has been changed into something sacred by the recognition that he has fallen under his own curse and that he has been the one all along whose touch on Theban soil has brought the defilement that manifests itself as plague.

He has also been transformed from tyrannos to basileus ${ }^{28}$-from a ruler whose power grew from the strength of his mind, to a ruler whose legitimacy came to him by birth. And now he has a different power. Before the change, he could send an embassy to Delphi, he could accuse men of plotting to overthrow him, and he could even credibly threaten a perceived enemy with death. These are all things an ordinary human tyrant can do. Now, Oedipus has new powers-or, rather, finds that he has had new powers for some time-the power to defile and the power to curse. Already he feels the power of his own curse falling on his head, and we know that in the future the curse he calls down on his sons will destroy them, defile them both as brother-killers. ${ }^{29}$

Oedipus at Colonus presents its audience with the opposite of a curse-a sacrament of un-defilement. Oedipus has arrived in Attica, polluted by his past. He is a suppliant now, seated on sacred ground. He is untouchable now on three counts, but the people of Colonus nevertheless want him to leave until they learn that he brings them a blessing. This begins to establish a relationship of xenia between Oedipus and the city, which will later be formalised through an exchange of support between Oedipus and Theseus. The establishment of xenia through such an exchange is a sacrament in that it establishes a friendship that is hedged around with ethical protections.

The first result of this friendship is that the chorus tells Oedipus how to conduct a sacrament to remove the defilement caused by his entry into sacred space. This his daughters will carry out on his behalf (466-500), but later, when he enters the sacred space in his last moments, he causes no defilement; he has 
already been consecrated, either by his cursed actions in the past or by the actions of the play.

Before the play is over, he will discover that he has other powers beyond what is normal for human beings, even for tyrants. In the prologue to the play we see that he is able to enter a sacred space with impunity, even that he seems to be drawn to the sacred space. Later we learn that he carries not a curse but a blessing to the land on which he will die; that is why Athens and Thebes are competing for the honour of his death. Towards the end of the play he will hear Zeus speak to him, while others hear only thunder. And at the very end he will cast aside his crutch, and, blind as he is, Oedipus will lead Theseus off stage to the place appointed for him to end his life.

Not all plays have such effects, but many do (or can do) and the ones that succeed in making the hero sacred are not all ancient. Audiences for Death of a Salesman sometimes report the sense of awe that takes them at the end, leaving them in silence, unable to applaud. That play too is sacramental theatre.

Such plays as these enact the consecration of a human being, one who is imperfect and has done wrong, perhaps, but one who has been elevated by the drama to a position for which we in the audience feel a sense of awe. This is the most powerful of the sacramental effects of theatre: to make the hero sacred.

\subsection{Sophocles' Philoctetes}

I conclude by asking about the place of sacrament in Sophocles' Philoctetes. Some sacraments affect the kind of attention demanded of an audience, others change the ethical climate around a scene. What sacraments occur around or within this play? Not surprisingly, they are sacraments of exclusion (remembered in the play) and sacraments of inclusion (within the plot).

The play hangs on two questions: how the outcast archer, Philoctetes, is to be brought back into his human community, the Greek army, and how the young son of Achilles, Neoptolemus, will respond to Odysseus' efforts to teach him to deceive. The play does not clearly answer the second question, about the boy's willingness to deceive the archer; he could well be lying right up to the end. ${ }^{30}$ Indeed, the young man's character is unlikely to be fully formed and displayed in a single day's action. Time-and his actions in the sack of Troywill show us his moral quality, as Heracles hints at the end (1440-44).

The first question-how to bring back the outcast-does receive an answer, and this involves sacrament. Philoctetes was cast out because of a cursed wound, which he received on entering a sacred precinct. He has responded with hatred to the cruelty of his being cast out, so that at the time of the play he has, in effect, cast himself out of the community to which he belongs (as the chorus recognises-1095). How can he be brought back into the fold? He is master of a powerful weapon, the bow of Heracles, with which he can defend himself against any attack, so long as he is free in the open air.

Sophocles' play explores two bad answers for most of its length-force and deception. The archer may be deceived into entering the boat, at which point he 
can be forced to go back to the army; in the confines of the boat his bow would not be a threat to his captors. Or he may be deceived into giving up the bow, after which he can be forced to go to Troy. Neither of these answers will do. Zeus evidently requires that the archer go willingly (1332); Zeus aside, an unwilling soldier is not a useful member of the army. Besides, no one can be forced or deceived into being part of a community.

The only way to bring Philoctetes back into the community is through friendship (again, as the chorus seems to recognise-1121). As we have seen, in the case of Oedipus at Colonus, actions that establish friendships in ancient Greek culture have a sacramental aspect, because they create something-a relationship - that may not be broken. Neoptolemus, attempting to form such a bond with Philoctetes, understands well how this is done:

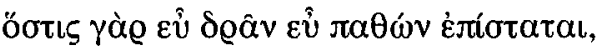

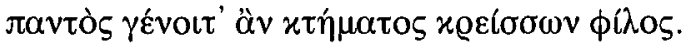

(Soph. Phil. 672f.)

One who knows how to give and receive benefits

Would be a friend more valuable than any treasure.

Philoctetes will lend him his bow, and Neoptolemus will return it (1291), recognising that their mutual support has made their friendship inviolable, even though Odysseus urges him to violate it for the sake of the army. The exchange has sacramental import, which must have been felt by the audience. But the audience knows that Neoptolemus has started this friendship on a false footing. And although the sacrament establishing it is not a failure, it does not lead to the trust at which Neoptolemus aims. Philoctetes realises that even if he trusts the boy, he cannot trust his older colleagues, and neither, he says, should the boy (1363-65). Philoctetes would not be safe in trusting himself to the friendship of a boy who has no standing in the army. And so this attempt through friendship fails.

In the end, friendship will bring him back, but it will be friendship from an unexpected quarter. His friend Heracles, who gave him the bow, will appear like a god from the machine, and Philoctetes will believe what he says. Friendship, not divinity is at work here: Heracles' voice is the voice he has longed to

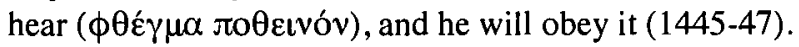

The epiphany of Heracles at the dénouement is neither a sacrament nor the result of a sacrament. Heracles' status as immortal is relevant only for the manner of his appearance; what he actually does in the play is something only a dear and trusted friend could do: he persuades Philoctetes to trust himself, his weapon, and his wound to the companionship of the army. The friendship that grounds this trust arises from a sacramental exchange from the distant past, in which Philoctetes carried out Heracles' last wish in return for the bow, thus cementing a friendship that extends beyond death. Although the play shows 


\section{THEATRE AS SACRAMENT}

how Zeus's plan will work out in practice, the sacraments underlying the plot do not call for Zeus's intervention.

\section{University of Texas at Austin}

\section{NOTES}

1. This is a consequence of the definition of the art of theatre that I proposed in my book, Woodruff (2008). The relevant element in the definition is 'in a measured space', which led me to treat theatre space as sacred (108-22). Since writing the book, I have come to see that I had left the concept of the sacred poorly defined, and said nothing about the process or the conventions that make it sacred-in short, the book left out the topic of sacrament. This paper tries to make up for that omission.

2. The prohibition implicit in the idea of the sacred is carried by the meanings of the Latin root for our word 'sacred': sacer. Along with 'sacred' and 'holy', this word means 'accursed' and 'detestable'.

3. Respect: Ehrfurcht. Most translations have 'reverence', which on my view would be Verehrung.

4. Beyond Good and Evil, tr. Judith Norman in Horstmann and Norman (2002), 160, section 263. I am grateful to Christopher Raymond for help with this passage.

5. Woodruff (2001a), 117, with note on $232 \mathrm{f}$.

6. Summoning the transcendent to inhabit a representation is a kind of theatrical sacrament which I will discuss below.

7. In practice, the line may be hard to draw. Visitors who treat a sacred place of worship with disrespect are not thereby trampling on God, but believers may react as if they were. Much conflict arises from this kind of confusion.

8. Woodruff (2008), 18 and passim.

9. I have discussed this in Woodruff (2008), 108-22.

10. Heracles, according to legend, fenced in the sanctuary at Olympus, the Altis (Pi. O . 10).

11. Woodruff (2008), 127-32.

12. On the altar call in today's art theatre, see Woodruff (2008), $121 \mathrm{f}$.

13. On the Theatre of War project, see http://www outsidethewirellc.com/projects/theater-ofwar/overview. See also $n .17$ below.

14. Scullion (2002) and Scullion (2005), esp. 32f.

15. Sourvinou-Inwood (2003), passim, especially on the ritual role of the chorus (50-53).

16. On this see the critical review by Mendelsohn (2013). Mendelsohn argues that Euripides' audience saw Heracles not as a veteran, but as a super hero. True, his violence has mostly not been conventional warfare, but his vulnerable, sometimes foolish humanity makes Heracles represent common human experience. For the production in question, it is fair to say that the veterans for whom Meineck designed the production had also been denied an experience of conventional warfare, and were no less stressed for all that.

17. I base this on my personal experience setting up readings of scenes from these plays for veterans and their families in a program called 'Veterans' Voices', supported by Humanities Texas in 2013.

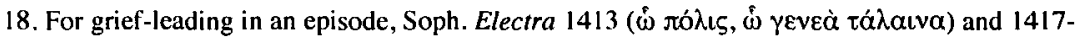
21 , where the Chorus step out of their roles as supporters of Electra and grieve for the whole misery of her family; for the same in an ode, see Philoctetes 674-717.

19. For an example of Athenian sentiment expressed by the Chorus, see Bacchae 386-402.

20. So Sourvinou-Inwood (2003), 51.

21. Sourvinou-Inwood (2003), 50-53 and 281-83.

22. Tr. Woodruff (1998).

23. On the relation between Dionysus and the production of ancient plays, see Easterling (1997), esp. 48. The topic has been much discussed by scholars.

24. A more literal translation: 'Come on cleansing foot', meaning that Dionysus' presence would purify Thebes and so save its people from plague.

25. Tr. Woodruff (2001) 


\section{PAUL WOODRUFF}

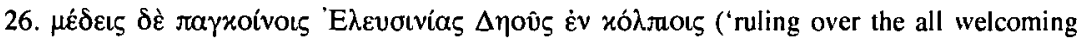
hollows of Eleusinian Demeter', Antigone 1119-21).

27. Of the parodos in the Antigone. Sourvinou-Inwood (2003), 51, writes: 'as the chorus processed in, singing a cult song the usual performance of which was processional, it would have been very difficult for the audience not to perceive this hymn as being sung also in the real world of the here and now.' This parodos is tied directly to the plot of the Theban play; if this was recognised as a cult song in Athens, then surely the fifth stasimon would be; although not processional, it is in no way tied to the plot.

28. When the chorus say they made him ruler for killing the Sphinx, they use the word for king ( $\beta \alpha \sigma i \lambda \varepsilon \cup$ us) for the first time in the play, at 1202, now that they know he is the legitimate ruler, son of the king,.

29. Oedipus at Colonus $421-27,450 \mathrm{f}$, 787-90, with 1375f. Some scholars have taken 1375f. as evidence that Oedipus delivered the curse before the start of the play, but Jebb and others hold that the curse was given as a result of Ismene's newv, during the play. On the controversy, see my note at Meineck and Woodruff (2003), 212.

30. At 1402, Neoptolemus appears to offer to take the archer home, as asked. But the ancient commentator thought this was another act of deception: 'He is deceiving and wants to take him to 'Troy' (393.3-4 Papageorgius, cited in Calder [19711, 167). See also Raubitschek (1986). Most modern scholars disagree; see Easterling (1978), 39, and Blundell (1989), 224n. The text leaves this open, so it is most likely that the poet means to leave us in suspense. 